\title{
Climate adaptation, transitions, and socially innovative action-research approaches
}

\author{
$\underline{\text { Inês S. Campos }}^{1}, \underline{\text { Filipe M. Alves }}^{1}, \underline{\text { João Dinis }}^{2}, \underline{\text { Monica Truninger }}^{3}, \underline{\text { André Vizinho }}^{1}$ and $^{\text {Gil Penha-Lopes }}{ }^{1}$
}

\begin{abstract}
Climate change may be a game-changer for scientific research by promoting a science that is grounded in linking the production of knowledge and societal action in a transition toward more sustainable development pathways. Here, we discuss participatory action-research (PAR) as a way of thinking and leading investigations that may promote incremental and transformative changes in the context of climate change adaptation research. Our exploration is addressed in the Portuguese context, where PAR and sustainable transition studies are still marginal, and adaptation processes are a recent topic on political agendas. We describe the characteristics of PAR and use two studies of adaptation to illustrate how research and practice co-evolve through interactive cycles. The two studies are works in progress, rather than completed PAR processes. Climate change adaptation is an ongoing and long-term process. Moreover, in Portugal, as in many regions of the world, climate change adaptation is a fairly new topic. Thus, both case studies are now initiating a long-term process of change and adaptation. The completion of one research cycle is a realistic expectation that we have achieved in the two case study experiences. In our discussion of the case studies, we consider how these experiences provide insights into the role of PAR for long-term regime changes. We conclude by pointing to the societal needs addressed by PAR, as a pragmatically oriented and context-specific research design. The approach can be complementary to other frameworks in sustainable transition studies such as transition management. Being more pragmatically oriented, PAR cycles may influence incrementally transformative changes that can be guided by transition management's long-term design for governing sustainable transitions.
\end{abstract}

Key Words: adaptation; participatory action-research; Portugal; transitions

\section{INTRODUCTION}

At the core of human evolution, adaptation and transitions are a constant and unavoidable challenge for people worldwide. However, considering the challenge of climate change, adapting to a changing environment may be only the tip of the iceberg; a societal transformation toward sustainability is needed to resolve the world's persistent problems (Westley et al. 2011, Pelling et al. 2015). Climate change may be a game-changer for scientific research by promoting a science that is grounded on linking the production of knowledge and societal action toward more sustainable development pathways (Pelling et al. 2015). In climate change science, adaptation refers to "the process, action or outcome in a system (household, community, group, sector, region, country) in order for the system to better cope with, manage or adjust to some changing condition, stress, hazard, risk or opportunity" (Smit and Wandel 2006:282). In this context, research gains from continuously reflecting on how it promotes a transition toward better adapted societies (Pelling 2010, O'Brien 2012).

The study of sustainable transitions (Markard et al. 2012) has evolved in the past decades as a scientific response to the challenge of governance for sustainable development (Meadowcroft 2009, Miller et al. 2014). Long-term dynamics and an interdisciplinary paradigm are central features of sustainability research (Avelino and Rotmans 2011). A transition is a long-term process ( $\geq 25-50$ years) characterized as a "gradual, continuous process of change where the structural character of a society (or a complex subsystem of society) transforms" (Rotmans et al. 2001:16). Sustainable transitions have been strongly rooted in innovation studies, from which emerges the nomenclature of "socio-technical regimes," "niches," and "landscape" (Markard and Truffer 2008). The regime is a "deep structure" (Geels 2011:28) that maintains the stability of the societal system. Therefore, transitions are often denoted as regime changes, and it is desirable that these changes follow a sustainable direction (Loorbach 2010). Within or outside the boundaries of the regime, there are less dominant and innovative constellations: the niches. The landscape is identified, in relation to the regime and niches, as a set of contextual features that influences these subsystems. Though many studies have focused on climate change-related topics, the main emphasis has been on mitigation, such as studies of energy transitions and urban mobility (Kemp and Rotmans 2004, Kern and Smith 2008). More recently, climate change adaptation has been approached from a sustainable transitions perspective, both conceptually and empirically (De Haan and Rotmans 2011, Nevens et al. 2013).

In the study of climate change adaptation, there is a significant body of literature arguing for the inclusion of participatory approaches in research (Amaru and Chhetri 2013, Fabricius et al. 2013). Participation allows for a continuous brokerage between scientific and lay knowledge because new governance and learning arrangements are expected to promote adaptability (Folke et al. 2005, Olsson et al. 2006). These frameworks are supported by participation, community involvement, and collective action (Hobson and Niemeyer 2011, Adger et al. 2013). Studies have also linked transformation and transition literature in designing frameworks to investigate climate change adaptation, perceived as a cyclical, incremental, and transformative process of change (Kates et al. 2012, Park et al. 2012).

Participatory action-research (PAR) is characterized by its continuous interactive cycles of research and action-engagement (McNiff 2013, Wittmayer and Schäpke 2014). Rather than following a linear, simplistic approach, PAR imposes a flexible, cyclical, and co-evolving process that arises from the meeting of practitioners and researchers (Badham and Sense 2006). This dynamic feature seems appropriate for studies of adaptation and

${ }^{1}$ Center for Ecology, Evolution and Environmental Changes (CE3C), University of Lisbon, ${ }^{2}$ Cascais Municipality, ${ }^{3}$ Institute of Social Sciences, University of Lisbon 
transition processes (Nevens et al. 2013). Here, we aim at understanding how PAR supports incremental and transformative change (i.e., a transition) in the context of adaptation. The analysis is based on two case studies in Portugal.

In Portugal, participation and deliberative processes have not been mainstream in political arenas, and adaptation planning activities are mostly characterized as managerial and top-down processes (Carneiro 2007, Alves et al. 2013). Planning adaptation is a new subject for the country's political agendas. A National Adaptation Strategy was proposed in 2010, but its implementation is still at early stages. At the local level, only three municipalities have a climate strategy. Participatory approaches are unusual in Portuguese environmental scientific research, and decisions resulting from participative processes are difficult to integrate in political arenas, mostly because they oppose conventional and standing decision-making processes (CarvalhoRibeiro et al. 2010, Schmidt et al. 2014). Portugal has also not received much attention from the transition research field. A review of published studies drawing from research in Portugal revealed few (Murray et al. 2007, Boavida et al. 2013), and these mostly focused on technological transitions for mitigating climate change impacts.

In the following section, we explain the PAR approach, including its relevance in transition research. We continue by relating the methodology and reflexive analysis of the PAR cycles, including the methods used and the resulting insights. In the discussion, we consider how these findings provide understanding of the role of PAR in the study of long-term regime changes. Our conclusion points to the needs addressed by PAR and its complementarities with other frameworks for future research.

\section{PARTICIPATORY ACTION-RESEARCH}

The term action research (AR) was coined by Kurt Lewin (1946), who introduced the concept in his 1946 paper Action Research and Minority Problems, which describes a looped action of research used as a tool to resolve conflicts among marginalized societal groups (Susskind et al. 1999). Succeeding Lewin and later Paulo Freire's (1972) first applications of AR to promote social inclusion, consensus, and democracy, the approach has been also extensively used in medicine (Baum et al. 2006, Bradley and Puoane 2007). AR differs from conventional research due to its cyclical nature: action and research progress block by block, forming an "interactive reflective cycle" (Baum et al. 2006:854). A three-step cycle of planning, implementation, and evaluation is often used (Alrichter et al. 2002). However, variations to this cycle have been developed in environmental science. For instance, the integrated sustainability assessment approach uses a four-step cycle, which includes diagnosis before planning (Jäger et al. 2008).

When AR is implemented through a continuous involvement of social actors, it becomes participatory action-research (PAR), which relies on the assumption that those being researched should actively participate in the process of researching (McNiff 2013). PAR can be defined as "an enquiry with people rather than on people" (Alrichter et al. 2002:130). Such enquiry with people may lead to the self-mobilization of communities, whereby "people participate by taking initiatives, independent of external institutions, to change systems" (Ashley et al. 2009:24). Most often, PAR implies that researchers and participants codetermine the objectives, questions, and methodologies by tapping "the perceptions of practitioners within particular, local practice contexts" (Argyris and Schön 1989:613). This process is linked to the characteristics of the action-group, who is responsible for leading the research and generally comprises both researchers and participants (Audet and Guyonnaud 2013). This group should be established at the initial stages of the process, but may take time to form or may even be the result of a first cycle. These dynamics characterize the forms of engagement and relations of trust and legitimacy established between researchers and participants (Ashley et al. 2009).

\section{Action-research in sustainable transitions}

Conceptual frameworks for investigating the co-evolving multilevel dynamics of socio-technical systems argue for integrating more reflexive and deliberative designs (Hendriks and Grin 2007, Voß and Bornemann 2011). Transition management (Rotmans et al. 2001, Loorbach 2010) is a governance approach in which future visions are co-created and shared to define short-term objectives that can meet long-term goals. Transition management is considered a new mode of governance for a new generation of long-term planning (Loorbach 2010, Loorbach and Rotmans 2010). The framework is AR oriented and seeks to promote, influence, and monitor sustainable transitions (Audet and Guyonnaud 2013). Transition management follows a four-stage cyclical method, engaging a group of selected frontrunners (or niche actors) in a transition arena (Loorbach 2010). Thus, the transition arena can be considered an action-group, whose members are selected by the researchers steering the transition management experiment. Arena actors envision potential futures and design and implement different strategies to pursue those futures. Monitoring and reflexive activities support the advancement of the transition.

\section{METHODOLOGY AND INSIGHTS}

Here, our application of AR emphasizes its participatory version (i.e., PAR). Taking stock of the literature reviewed, the discussion is illustrated by two case studies in Portugal: the Coast of Ílhavo and Vagos, and the Cascais municipality (henceforth referred to as cases 1 and 2, respectively).

We implemented the case studies, which are characterized in the context of climate change adaptation (Table 1), according to a set of criteria: innovation (in the Portuguese context), stakeholder groups represented, external environmental pressures and climate-related impacts, and stage of the adaptation process (e.g., assessment, planning, implementation, monitoring; Schmidt-Thomé and Klein 2013). The objectives of the case studies were to promote sustainable adaptation processes and investigate the socio-political, ecological, and economic features of climate change adaptation. As participants became involved, new case-specific objectives were added to each study. The studies followed four-step cycles: diagnosis (of the problem), planning (the research activities), implementation (of the research activities co-created with the participants), and evaluation (of the results).

The studies are works in progress, they are not completed PAR processes. Climate change adaptation is not only an ongoing and long-term process, but is also a fairly new issue in Portugal. Thus, both case studies are now initiating their adaptation processes, 
Table 1. Characterization of two participatory action-research case studies in Portugal, in the context of climate change adaptation.

\begin{tabular}{llll}
\hline \hline Case study & Innovation & $\begin{array}{l}\text { Stakeholder groups represented by } \\
\text { the participants involved }\end{array}$ & $\begin{array}{l}\text { External pressures and climate- } \\
\text { related impacts }\end{array}$ \\
& & $\begin{array}{l}\text { Stage of adaptation process } \\
\text { (Lim and Spanger-Siegfried } \\
\text { 2004, Schmidt-Thomé and } \\
\text { Klein 2013) }\end{array}$ \\
\hline
\end{tabular}

\begin{abstract}
Municipalities of Ílhavo and Vagos (coastal zone, northern Portugal) Collaborative long-term Municipal and district adaptation plan for the coast administrations, regional and central governmental administrations, Aveiro Harbor, nongovernmental organizations, local university scholars, resident associations, fisher and farmer associations, surf schools, beach business owners
\end{abstract}

Municipality of Cascais (city-center in Portugal)

One of first three cities in Municipality policy makers and Portugal to have a Climate planners, health managers and Strategy (Cascais 2010)

\author{
Erosion, rising sea-levels, \\ extreme events (climatic impacts \\ already perceived) \\ Assessment and planning
}

Heat waves, flooding, human
health (climatic impacts are
anticipated based on future
climate scenarios)

\author{
Planning and
implementation
}

and the expectation of researchers has been to complete one research cycle. In both studies, researchers were concerned with forming an action-group who would continue to drive the adaptation process. In Case 1, this task was more demanding because the social actors were largely disconnected from each other. In Case 2, forming an action-group benefited from the participants involved, who were active networkers and had firm connections to other stakeholders. However, in Case 2, participants were mostly institutional actors, and representatives of local communities were poorly included. Furthermore, both studies comprised technical and nonparticipatory components, which resulted from identical needs and were aimed at supporting the implementation of prioritized adaptations. We next decribe each of the case studies.

\section{Case 1}

The region for Case 1 is located in northern Portugal, on the Atlantic Coast of the Ílhavo and Vagos municipalities. The area extends from the South of Aveiro Harbor along a coastal stretch of $20 \mathrm{~km}$ between the sea and the Aveiro Lagoon. The region was recognized as one of the most vulnerable low-lying coasts in Europe insofar as storm surges and flood risks (Coelho et al. 2009, Schmidt et al. 2014). A sea-level rise of up to $1 \mathrm{~m}$ in 2100 would aggravate this vulnerability (Fortunato et al. 2013). Nevertheless, despite the already felt environmental pressures, previous research highlighted the absence of an adaptation strategy or action-plan (O'Riordan et al. 2014). Moreover, other studies found that residents in the region considered the University as a neutral institution that should facilitate planning (Schmidt et al. 2014).

Participatory action-research cycle and methods

The research activities are summarized in Table 2. The diagnosis stage was informed by the findings delivered by previous studies in the region, which were confirmed by initial conversations with stakeholders, who stated that a plan was needed to respond to perceived coastal vulnerabilities and risks. Thus, researchers proposed facilitating the making of a long-term climate change adaptation action-plan.

A challenge for this study was to build trust between a diversity of stakeholders so that all could reflect together on different and sometimes controversial adaptation options and reach consensus. The scenario workshop (Andersen and Jæger 1999) method provided a collaborative forum for discussion between diverse stakeholder groups, with the aim of creating a plan for the long term. For successful implementation of the method, it was fundamental to form a representative group of stakeholder interests. It was important that participants were leaders or influential persons in the groups they represented, but also prone to be involved in a productive discussion and collaborative process. Finally, involving political actors and all those who would be responsible for implementing a plan was also central.

The process of forming an action-group took time, and a series of meetings with local stakeholders groups or their individual representatives was held. In these meetings, people claimed that there was not enough information provided on local climate change impacts. To respond to this information request, two seminars (open to anyone who wished to attend) were organized, with presentations on impacts and potential adaptations, preparing participants for the subsequent research activities. The seminars contributed to establishing a relationship of trust between researchers and the participants, who afterwards were invited to join the subsequent scenario workshop sessions.

The scenario workshop method was implemented on two separate days. On the first day, participants critiqued potential future storylines, based on climate change scenarios, and developed a common, shared vision for their region. On the second day, the action-plan was developed. Between the two workshop days, 
Table 2. Synthesis of participatory action-research on the coast of Ílhavo and Vagos (Case 1).

\begin{tabular}{|c|c|}
\hline Time frame & PAR activity \\
\hline \multirow[t]{2}{*}{ November 2013-February 2014} & Begin contacting representatives of various stakeholders; \\
\hline & Present proposal for making an inter-municipal climate change adaptation action-plan \\
\hline \multirow[t]{2}{*}{ February-March 2014} & Municipal stakeholders gradually become active participants; \\
\hline & $\begin{array}{l}\text { Two seminars held: presentations of researchers and invited speakers on climate change and } \\
\text { adaptation strategies for coastal regions }\end{array}$ \\
\hline \multirow[t]{3}{*}{ April 2014} & Scenario workshop, day 1 (26 participants): critique and vision; \\
\hline & $\begin{array}{l}\text { Critique of three extreme alternative future storylines (i.e., do nothing, protecting everything, or } \\
\text { relocate); }\end{array}$ \\
\hline & $\begin{array}{l}\text { Common vision for the coast in } 2100 \text { : local populations and infrastructures are protected, current } \\
\text { coastline is maintained, and natural ecosystem is preserved }\end{array}$ \\
\hline \multirow[t]{3}{*}{ May 2014} & Scenario workshop, day 2 (26 participants): action-plan; \\
\hline & Adaptation pathways and tipping points until 2100 \\
\hline & $\begin{array}{l}\text { Adaptation actions in the plan: sand nourishment operations, sand dike to strengthen the dune } \\
\text { system, submerged detached breakwater (pending further studies), seawalls and groynes, } \\
\text { monitoring of sea levels and of coastal erosion }\end{array}$ \\
\hline June-July 2014 & Follow-up interviews with 12 participants \\
\hline September 2014-March 2015 & $\begin{array}{l}\text { Economic cost-benefit analysis (November 2014-March 2015): assessment of technical options } \\
\text { for each adaptation measure, as well as of monetary costs, avoided costs, and benefits }\end{array}$ \\
\hline \multirow[t]{2}{*}{ June 2015} & $\begin{array}{l}\text { Final presentation to stakeholders of the plan (June 2015): approximately } 60 \text { participants attend } \\
\text { presentation of a full report to the wider public; }\end{array}$ \\
\hline & $\begin{array}{l}\text { Action-group (i.e., policymakers, researchers from the local university) applies for grants for } \\
\text { implementing the plan; other municipalities want to experiment with the same methodology for } \\
\text { climate change adaptation planning }\end{array}$ \\
\hline
\end{tabular}

researchers gathered necessary information (e.g., secondary effects of different adaptation options) to prepare for the second day's discussions. This information was shared (via email) before the second workshop day. During this interval, it was found that another method should be included to aid in deciding between different adaptation options and in designing a long-term actionplan. Thus, the adaptation pathways and tipping-points method was adopted. This method was developed by Haasnoot et al. (2013) to support decision-making in the context of long-term planning processes, which need to deal with a high level of complexity and uncertainty. Thus, integrated in the scenario workshop context, the method was meant to aid participants in working through the different levels and types of uncertainty while they co-created an action-plan.

Throughout the second workshop session, participants designed the pathways. These pathways are represented by graphs in which each horizontal line corresponds to an adaptation action, to be maintained until specific conditions are altered and a new policy is needed (e.g., sea-level rises $>40 \mathrm{~cm}$ and a dike needs to be built). The method allows identifying a set of possible actions (adaptation measures), which may change in time according to variations in the natural system. By integrating the adaptation pathways in the scenario workshop method, the final outcome was a dynamic adaptation plan for the following 75 years.

Following the scenario workshop, half of the participants were interviewed to evaluate the PAR activities. Workshop transcripts and interviews were helpful to set the goals for the follow-up research activities. Policymakers and spatial planners manifested the need for more information concerning the possible costs and benefits of implementing the plan. Thus, an economic cost- benefit analysis was developed for all the adaptation actions and technical variations listed in the final pathways. Lastly, a report with a synthesis of the results and conclusions of all the research activities was presented to participants, as well as a number of invited political, civil society, and business representatives from other municipalities in the region. This final presentation closed a first PAR cycle, yet coastal adaptation in Ílhavo and Vagos is a work in progress.

Creating the action-group through the scenario workshop interactions was central to ensuring that the research continues to support a transition toward better adapted communities. The action-group included policymakers, residents, and local researchers; the latter integrated the research team while delivering the economic assessments. The group is applying for grants that may help finance further studies of the effects of some adaptation options suggested. Studies are also being developed to replicate the planning experience in other regions in Portugal. Finally, building on the knowledge and experiences gained, the Ílhavo municipality is participating in a capacity-building program for continuing to develop the adaptation process with local and regional stakeholders. This program is benefitting from international financial mechanisms, currently managed by the Portuguese Environmental Agency.

\section{Insights}

The first contact with stakeholders pointed to a communication gap between local communities and decision makers. Social actors had participated in other investigations, but complained that their involvement did not produce real, perceivable outcomes, and that their opinions had never been integrated in previous policyplanning experiences. There was also a distrust of political actors, 
who allegedly were not well aware of the problem: "One thing I can't stand is hearing decision makers talking about relocating people on the first line. There is not a first line; it's all the same sea-level!" (Fisherman).

Researchers called on political actors to participate. During this research stage, storms destroyed beach bars and endangered houses built on the shoreline. Images of these storms appeared on national television. These conditions created a window of opportunity for closer engagement. Policy makers and planners became more interested in the study, and some residents contacted directly the research group at the University of Lisbon to express their interest in participating.

Because risks and vulnerabilities are already being felt, stakeholders were driven by the will to sustain their current way of life. This goal was explicit in the consensual vision of the group for the following 75 years that resulted from the first workshop, which could be summarized as: Local populations and infrastructures are protected, the current coastline is maintained, and the natural ecosystem is preserved. This vision entails objectives which are likely to be conflicting (i.e., holding the line and preserving the natural ecosystem). Nevertheless, maintaining the current state seemed to be the most important goal, as one resident stated: "I want to be part of a society that leaves the land as it is to my grandchildren."

The active participation of all in the planning process was central for building trust. One resident stated, "For me, the best was to be able to reason with politicians, find out we all want the same thing." A municipal planner stated, "From the engineers' explanations, I learned a lot about the different options."

Participants also remarked that visual methods, and being able to work directly with the adaptation pathways graphs, facilitated discussions and their understanding of the problem. For example, one resident stated, "We were more present in the land while using the drawings and graphs."

The final pathways (produced on the second workshop day) included a set of consensual actions until 2100. The main actions were: sand nourishment operations; a sand dike in a particularly vulnerable stretch; a submerged detached breakwater; seawalls and groynes; and monitoring of sea levels and coastal erosion. Political commitment and lack of funding, however, were perceived to be important barriers for implementation. Participants believed the possibility for implementation would increase if it could be proven that the benefits of holding the present coastline would be higher than the costs of inaction. For example, a municipal planner said, "Knowing the [monetary] benefits of these measures can be key to pushing for political commitment, but the costs are going to be high."

Thus, following the workshops, researchers produced and presented the results of an economic assessment. The conclusions supported the priorities identified in the final pathways. Nevertheless, the analysis equally pointed to the need for further technical studies concerning options such as a submerged breakwater, which has never been done on the Portuguese Atlantic coast. Sand nourishment operations were equally found to have economic benefits that justified the high costs. Nevertheless, a new way of living on the coast may be inevitable. A local engineer commented, "No matter how much sand we put, you will never see those miles of dunes again."
Concurrently, a long-term adaptation process will mostly likely be transformational because hard engineering infrastructures for holding the coastline will probably have significant effects on the ecosystem, despite the group's future vision for both holding the line and maintaining the present system state.

\section{Case 2}

The region for Case 2 is the city of Cascais, located approximately $25 \mathrm{~km}$ west of Lisbon. The region is a national and international tourist destiny, and the adaptation planning process is integrated in a broader transition toward a greener, more sustainable city. Cascais has been rated as a top sustainable destiny (by the European Union, http://www.qualitycoast.info/?page $\mathrm{id}=708=)$. The city is one among three in Portugal to have a climate change adaptation policy. The Cascais Strategic Plan for Climate Change (CSPCC; Cascais 2010) integrates a mitigation policy and an adaptation policy. At the onset of the PAR process, the adaptation document was only known by a small group of municipal policy makers and scientific experts and suggested a set of 15 integrated and cross-sectorial measures that were considered priorities.

\section{Participatory action-research cycle and methods}

The research activities are summarized in Table 3. In 2013, the municipality's Agenda 21 Cabinet (Cascais adhered to the United Nations Development Program's Agenda 21 program) and the research group partnered up, with the goal of promoting implementation through a reprioritization and assessment of potential adaptations to be substantiated by a diversity of stakeholders groups, including representatives of key municipal departments (e.g., health, education, communication) and other social actors. However, from an original plan of having two workshops, the PAR grew to comprise eight workshops, two surveys, and a cost-effectiveness analysis.

The workshops and survey results respectively highlighted adaptation priorities and the main barriers and opportunities for implementation. The subsequent economic analysis focused on providing an assessment of some priorities identified through the workshops, thus delivering information requested by participants on the costs and effectiveness of measures, with the purpose of aiding the decision-making process. Finally, structured interviews were performed with nine policy makers and planning specialists involved in the Cascais strategic plan. These interviews aimed at evaluating the perceived strengths and weaknesses of the first PAR cycle and the motivations to continue the adaptation process.

Thus, this PAR process was characterized by a sequence of responses to requests for additional types of information, which led to involving a multidisciplinary research team (i.e., sociologists, economists, environmental engineers). Researchers and municipal representatives of the Agenda 21 Cabinet formed the initial action-group. However, as the PAR cycle developed, the group grew to include other researchers, municipal stakeholders, and city residents.

The final set of workshops included: a commencement workshop, where representatives from all municipal departments were present for a reassessment of the adaptation actions proposed by the Cascais strategic plan; six workshops designated as "sectorial," which aimed at working through the different adaptation options for each sector of the strategic plan; and one 
Table 3. Synthesis of participatory action-research in Cascais Municipality (Case 2).

\begin{tabular}{l}
\hline Time frame \\
\hline
\end{tabular}

July 2013

Commencement workshop, revisiting the Cascais Strategic Plan for Climate Change:

20 policymakers and spatial planners of different departments; re-prioritize and substantiate adaptations for the plan;

Examples of priorities: awareness raising, water efficiency programs, guaranty the reduction of diffuse discharge or pollutants in the water, sustainable school, green corridors in the city

September 2013 and September 2014 Tourism and coastal workshops at the Cascais Greenfest:

Tourism: 45 municipal agents and business owners brainstorm adaptation actions that can promote a sustainable tourism;

Coastal: 19 residents and business owners map potential protective measures for coastal areas; Examples of priority measures for these sectors: less water wasted to reduce costs for tourism infrastructure, construction of a groyne for coastal protection

October-November 2013

Municipality survey: online survey to municipal technicians and policy makers (99 responses); Main barriers identified for implementation: political will, lack of funding;

Main opportunities: reducing risk and vulnerabilities, participation and citizen engagement

November 2013

Biodiversity, residents, and water resources workshops:

Biodiversity and water resources: municipal technical specialist and spatial planners;

Residents: representatives of the six municipality districts;

Average of 10 participants in each workshop;

Examples of priority measures for these sectors: reforestation, urban farming, reduce water waste, eliminate water pollution focal points

February 2014

Education and health workshops:

Education: 19 school representatives, teachers, municipal communication department;

Health: 18 hospital and health centre representatives, state and municipal policy makers;

Examples of priority measures for these sectors: information campaigns on climate change and heat waves, legislation for bioclimatic construction

February-March 2014

Survey of city residents: personal interview survey (1885 valid responses);

Main barriers identified for implementation: political will, lack of funding;

Economic assessments of adaptations is considered crucial to support action ( $90 \%$ of respondents)

January-May 2015

Cost-effectiveness analysis: identify costs, benefits, effectiveness, and secondary effects of three

highest priority adaptation options during the first research cycle: green corridors, water retention

gardens, sustainable school

June 2015

Feedback interviews: assess participatory experiences;

Learn about impact of participatory action-research on policy integration because the Cascais

Strategic Plan for Climate Change is being annexed to the 2015 revision of the Land Use Plan

residents workshop. In the commencement and sectorial workshops, a list of measures from the Cascais strategy and other sources (e.g., United Nations Development Program) was provided for discussion and ranking. Participants were tasked with particular exercises, first done individually, then discussed in groups, and finally shared with the whole group by appointed spokespersons. Toward the end of each workshop, individual suggestions were compared to the group rankings to develop an agreed-upon final prioritization of adaptations. The tourism, coastal, and residents workshops had a different structure. The tourism workshop involved brainstorming possible economic benefits and opportunities of adaptations for that sector. The coastal workshop involved mapping potential adaptation options for coastal regions. The residents workshop brought together 10 representatives from the six city districts to discuss how local community resources could complement adaptation strategies and actions (e.g., the possibility for green roofs as a measure against flooding).

Agenda 21 partners collaborated with researchers in conducting two surveys: a survey of the technical body of diverse municipality departments, and a survey of local residents. Both surveys were initially proposed by the municipal partners with the goal of understanding the perceived climatic vulnerabilities and the barriers and opportunities for implementing adaptations. The survey results highlighted additional information requests, namely the importance of economic analysis for promoting the implementation of priority adaptation actions. Thus, an economic cost-effectiveness analysis was done for the top three priorities, i.e., green corridors, water retention gardens, and a sustainable school, which resulted from the final aggregated results of the seven workshops.

Following this first cycle of research activities, a progress report was produced with the results of the workshops, surveys, and economic analysis. The report was presented to municipal stakeholders. As in Case 1, the Cascais PAR process is still ongoing, led by the action-group formed by researchers and participants, and is now developing a second research cycle. This new cycle is focused on integrating the different adaptation options in other municipal policies and programs and continuing to develop economic assessments for implementing a set of 13 top priority measures. Priorities were identified in the seven sectorial workshops, but were not all assessed for costs and 
benefits during the first research cycle. Furthermore, a municipal budget has been allocated for implementing these measures.

\section{Insights}

In feedback interviews, municipal partners found that the prioritized cross-sectorial adaptation actions in the workshops, such as green corridors or the sustainable school (an environmental education program; Table 3), were congruent with the city's sustainability goals. According to feedback interviews with municipal partners all, except one, found that "climate change adaptation policies should contemplate medium and longterm action-plans to address perceived and expected climate change impacts, while promoting a transition to a more resilient and sustainable society."

However, the two surveys identified that political will and lack of funding could be barriers for implementation. In the residents survey, $90 \%$ of respondents found that economic assessments of adaptations would be crucial to gain political commitment and the allocation of adequate financial resources. Thus, municipal partners strongly pushed for developing those studies, and a costeffectiveness analysis was done for three adaptations considered priorities. The results of this analysis validated the top priorities as being cost-effective options.

In feedback structured interviews, municipal partners highlighted that PAR provided: "better policy integration among departments," "better dissemination and knowledge sharing on the topic of climate change," "a collective vision for the future of the municipality," and "better technical validation in supporting political decisions and planning processes." Policy makers and spatial planners also stated that forthcoming PAR cycles should engage society at large. The people directly involved in the first cycle were from either a municipal department or a partner institution (e.g., schools). Some stakeholders only participated once and were not genuinely involved, for instance in the case of the tourism and residents workshops. A municipal partner stated, "More stakeholders need to be called, like local associations, farmers, and tourism and golf entrepreneurs."

PAR was considered successful in promoting a higher level of policy integration that could support further implementation of the prioritized actions. This has been illustrated by the inclusion of the CSPCC, and the new recommended priorities, as an appendix to the 2015 revision of the Cascais Land Use Plan, which the municipal stakeholders interviewed agreed was reinforced by the research.

\section{DISCUSSION}

PAR is guided by the principle of linking knowledge and action (McNiff 2013). The question is if this way of practicing research supports incremental and transformative change (i.e., a transition) to a better adapted and sustainable society. In addressing this question, case study experiences lead to a reflection on how PAR unleashes sources of adaptability in ways that conventional technical scientific research does not.

PAR studies illustrate learning experiences (Collins and Ison 2009) of new modes of connecting social actors previously disengaged in planning, establishing collaborations (e.g., Case 1), and facilitating social learning processes (e.g., Case 2). These experiences seem to encourage collective action dynamics (Adger et al. 2013) and offer the possibility of accounting for the needs and expectations of a wider number of beneficiaries who were previously excluded from planning adaptations (Tompkins et al. 2008, Spaling et al. 2011). While facilitating new connections and relations between local groups and individuals (e.g., Case 1), PAR studies also helped to suppress the distance between private stakeholders and public actors by providing a strong body of updated knowledge (climatic, social, and economic). The studies provided a flexible methodological framework that embraced all levels of subject knowledge into a pragmatically well-explained path for decision support. For instance, both studies included economic analysis requested by local practitioners, who believed these data would garner political commitment toward the implementation of the adaptations selected as priorities. Thus, the PAR cyclical dynamics encouraged a continuous strategic reflection on how to steer the planning process and promote action. This co-evolution of action and research develops adaptability in ways that are not possible through more analytical and linear approaches in which the main focus is on devising concrete technical solutions, often imposed on society as an accomplished result (Voß and Kemp 2006, Stirling 2008). Undoubtedly, providing a body of technical-scientific knowledge has been important. Stirling (2008) discusses this point, which directs attention to the dichotomy between analytical (quantitative, expert-based) and participatory (qualitative, deliberative, democratic) approaches in relation to decisionmaking and social appraisal. In line with Stirling's (2008) reasoning, the case studies illustrate that both types of knowledge are fundamental. However, PAR offers a structure for linking these two types of knowledge production in a reflexive planning process.

It has been argued that scientists need to move from professional, specialized research toward interpreting and integrating different systems of knowledge, and acting as brokers in establishing a continuous dialog and learning process between science and practitioners (Folke et al. 2005, Sayce et al. 2013). In both case studies, the academics involved were from various scientific disciplines in the environmental and social sciences, but were also skilled and experienced facilitators of participatory techniques. The latter competences are considered important to motivate participants and establish multidirectional channels for exchanging information and promoting a constructive dialog (Avgitidou 2009, Sayce et al. 2013). Legitimacy and trust were achieved both by seeking strategic local partners (e.g., municipal policymakers) and by building successful narratives (Raven et al. 2016) around the societal and economic opportunities that could arise through adaptation.

The engagement dynamics observed raise the issue of power. Avelino and Rotmans' (2011) analysis of power relations in the context of transitions distinguishes between innovative, transformative, and constitutive exercises of power. PAR seems mostly to exert innovative power: it purposely promotes new relations, collaborations, and dialog between actor-groups that were previously disengaged. While interfering with established local power relations, PAR promotes the capacity of actors to create new fora for collective dialog (e.g., Case 1) and new dynamics in institutional decision-making processes (e.g., Case 2), which may influence incremental transformative changes. 
In PAR, there are no a priori decisions on what types of actors to involve. Instead, this selection is a first result of an explorative engagement moment and is grounded in baseline knowledge of local needs, preferences, governance frameworks, and dominant decision-making mechanisms. Throughout the action cycles, there may not be a selective process, but rather incremental engagement as different stakeholders are gradually integrated in the planning process (e.g., Case 2). In the Portuguese context, a challenge for PAR has been integrating participatory outcomes in concrete policies, planning activities, and development programs. Planning and environmental policy-making in Portugal have been characterized as institutionally puzzling, encompassing a panoply of governmental agencies (Schmidt et al. 2013), and typically informed by a top-down managerial approach (Schmidt et al. 2014). In this context, working with regime actors in changing the status quo of policy-making processes may be more effective than producing academic exercises with local stakeholders and innovators (CarvalhoRibeiro et al. 2010). This approach would be contrary to transition management, in which innovators or niche actors lead the transition arena (Loorbach 2010). However, in transition management (Loorbach 2010), dominant political interests and practices in ways of governing may also be central obstacles for integrating new visions for the future and long-term goals in transitions experiences (Meadowcroft 2009, Smith and Kern 2009). However, by continuously adjusting to local contexts and to the intricacies of political and administrative processes, PAR can work to influence sustainable transitions in the long term through its continuous action cycles for reaching short-term goals. Therefore, although case studies illustrate how PAR dynamics of engagement are sometimes contrary to transition management experiments, from a long-term perspective, these dynamics may be complementary.

\section{CONCLUSION}

As a game-changer for science, climate change promotes a research practice in constant transformation that needs to be innovative, reflexive, and recreate itself to meet the need for linking knowledge and action. From a systems thinking perspective, PAR could be said to emerge through the coevolution of science and practice experiments, the two domains being interdependent components. PAR triggers new dynamics for collective decision-making that support a sustainable direction in transformational adaptation. The approach is able to uncover the intricacies of planning and political processes, taking a close account of context-specific challenges for implementation. These challenges may be difficulties in translating decisions resulting from participative processes into effective policies, which need to be addressed for promoting short- and long-term political commitments. While building a support base from a wide group of stakeholders, PAR encourages socio-political legitimacy and trust for the results achieved such as decisions made on adaptation priorities. Yet, rather than based on a conceptualization of niche and regime actors, inclusion in PAR is strongly linked to contextual factors such as governance arrangements and mechanisms that support or constrain the integration of participation in policy-making. The action-involvement strategies may be contrary to transition management, namely its proposal for selecting frontrunners and forming transition arenas. In PAR, the action-group is the product of a sometimes chaotic, unpredictable, and incremental engagement process. Nevertheless, both PAR and transition management can be complementary in transition studies. Being more pragmatically oriented, PAR cycles can influence incrementally transformative changes that can be guided by transition management's long-term design for governing sustainable transitions. Future research could benefit from articulating the two approaches in climate change adaptation studies.

Responses to this article can be read online at: http://www.ecologyandsociety.org/issues/responses. $\mathrm{php} / 8059$

\begin{abstract}
Acknowledgments:
The funding for publishing the article was granted under FCT Ref. UID/BIA/00329/2013. The authors acknowledge and are thankful to all the stakeholders involved in the case study research. We are particularly appreciative of the Municipality of Cascais, the Municipality of Vagos, the Municipality of Íhavo, the Aveiro Harbor Administration, and the Portuguese Environmental Agency for their collaboration throughout our research. We also thank the reviewers in the double-blind review process for their valuable advice, suggestions, notes, and insights, which resulted in a much improved version of the paper. The research leading to this paper was done in the context of FP7 project BASE (Bottom-up Climate Adaptation Strategies for a Sustainable Europe: http://base-adaptation.eul), grant agreement 308337. However, the contents of the paper do not reflect the views or opinions of the European Commission. Finally, we thank the Fundação para a Ciência e Tecnologia (scholarship SFRH/BPD/65977/2009) for financial support to Gil Penha Lopes.
\end{abstract}

\section{LITERATURE CITED}

Adger, W. N., J. Barnett, K. Brown, N. Marshall, and K. O'Brien. 2013. Cultural dimensions of climate change impacts and adaptation. Nature Climate Change 3(2):112-117. http://dx.doi. org/10.1038/nclimate1666

Alrichter, H., S. Kemmis, R. McTaggart, and O. Zuber-Skerritt. 2002. The concept of action research. Learning Organization 9 (3):125-131. http://dx.doi.org/10.1108/09696470210428840

Alves, F. L., L. P. Sousa, M. Almodovar, and M. R. Phillips. 2013. Integrated Coastal Zone Management (ICZM): a review of progress in Portuguese implementation. Regional Environmental Change 13(5):1031-1042. http://dx.doi.org/10.1007/s10113-012-0398$\mathrm{y}$

Amaru, S., and N. B. Chhetri. 2013. Climate adaptation: institutional response to environmental constraints, and the need for increased flexibility, participation, and integration of approaches. Applied Geography 39:128-139. http://dx.doi. org/10.1016/j.apgeog.2012.12.006

Andersen, I.-E., and B. Jæger. 1999. Scenario workshops and consensus conferences: towards more democratic decisionmaking. Science and Public Policy 26(5):331-340. http://dx.doi. org/10.3152/147154399781782301 
Argyris, C., and D. A. Schön. 1989. Participatory action research and action science compared: a commentary. American Behavioral Scientist 32(5):612-623. http://dx.doi. org/10.1177/0002764289032005008

Ashley, H., N. Kenton, and A. Milligan, editors. 2009. Community-based adaptation to climate change. Participatory learning and action 60. International Institute for Environment and Development, London, UK.

Audet, R., and M.-F. Guyonnaud. 2013. Transition in practice and action in research. A French case study in piloting ecoinnovations. Innovation: European Journal of Social Science Research 26(4):398-415. http://dx.doi.org/10.1080/13511610.2013.850019

Avelino, F., and J. Rotmans. 2011. A dynamic conceptualization of power for sustainability research. Journal of Cleaner Production 19(8):796-804. http://dx.doi.org/10.1016/j.jclepro.2010.11.012

Avgitidou, S. 2009. Participation, roles and processes in a collaborative action research project: a reflexive account of the facilitator. Educational Action Research 17(4):585-600. http://dx. doi.org/10.1080/09650790903309441

Badham, R. J., and A. J. Sense. 2006. Spiraling up or spinning out: a guide for reflecting on action research practice. International Journal of Social Research Methodology 9 (5):367-377. http://dx.doi.org/10.1080/13645570600659540

Baum, F., C. MacDougall, and D. Smith. 2006. Participatory action research. Journal of Epidemiology and Community Health 60(10):854-857. http://dx.doi.org/10.1136/jech.2004.028662

Boavida, N., M. Baumann, A. B. Moniz, J. Schippl, M. Reichenbach, and M. Weil. 2013. Technology transition towards electric mobility - technology assessment as a tool for policy design. IET/CICS.NOVA-Interdisciplinary Centre on Social Sciences, University of Lisbon, Portugal. [online] URL: http://hdl.handle. $\underline{\text { net/10362/14158 }}$

Bradley, H. A., and T. Puoane. 2007. Prevention of hypertension and diabetes in an urban setting in South Africa: participatory action research with community health workers. Ethnicity and Disease 17:49-51. [online] URL: http://hdl.handle.net/10566/182

Carneiro, G. 2007. The parallel evolution of ocean and coastal management policies in Portugal. Marine Policy 31(4):421-433. http://dx.doi.org/10.1016/j.marpol.2007.02.002

Carvalho-Ribeiro, S. M., A. Lovett, and T. O’Riordan. 2010. Multifunctional forest management in northern Portugal: moving from scenarios to governance for sustainable development. Land Use Policy 27(4):1111-1122. http://dx.doi.org/10.1016/j. landusepol.2010.02.008

Cascais. 2010. Plano Estratégico de Cascais face às Alterações Climáticas. [Cascais Strategic Plan for Climate Change]. Cascais Municipality, Cascais, Portugal. [online] URL: http://www.cmcascais.pt/sites/default/files/anexos/gerais/ag21_plano estrategico cc alteracoes climaticas.pdf

Coelho, C., R. Silva, F. Veloso-Gomes, and F. Taveira-Pinto. 2009. Potential effects of climate change on northwest Portuguese coastal zones. ICES Journal of Marine Science 66(7):1497-1507. http://dx.doi.org/10.1093/icesjms/fsp132
Collins, K., and R. Ison. 2009. Jumping off Arnstein's ladder: social learning as a new policy paradigm for climate change adaptation. Environmental Policy and Governance 19(6):358-373. http://dx.doi.org/10.1002/eet.523

De Haan, J. H., and J. Rotmans. 2011. Patterns in transitions: understanding complex chains of change. Technological Forecasting and Social Change 78(1):90-102. http://dx.doi. org/10.1016/j.techfore.2010.10.008

Fabricius, C., E. Koch, H. Magome, and S. Turner, editors. 2013. Rights, resources and rural development: community-based natural resource management in southern Africa. Earthscan, London, UK.

Folke, C., T. Hahn, P. Olsson, and J. Norberg. 2005. Adaptive governance of social-ecological systems. Annual Review of Environment and Resources 30:441-473. http://dx.doi.org/10.1146/ annurev.energy.30.050504.144511

Fortunato, A. B., M. Rodrigues, J. M. Dias, C. Lopes, and A. Oliveira. 2013. Generating inundation maps for a coastal lagoon: a case study in the Ria de Aveiro (Portugal). Ocean Engineering 64:60-71. http://dx.doi.org/S0029801813001005

Freire, P. 1972. Pedagogy of the oppressed. Penguin, Harmondsworth, UK.

Geels, F. W. 2011. The multi-level perspective on sustainability transitions: responses to seven criticisms. Environmental Innovation and Societal Transitions 1(1):24-40. http://dx.doi. org/10.1016/j.eist.2011.02.002

Haasnoot, M., J. H. Kwakkel, W. E. Walker, and J. ter Maat. 2013. Dynamic adaptive policy pathways: a method for crafting robust decisions for a deeply uncertain world. Global Environmental Change 23(2):485-498. http://dx.doi.org/10.1016/j.gloenvcha.2012.12.006

Hendriks, C. M., and J. Grin. 2007. Contextualizing reflexive governance: the politics of Dutch transitions to sustainability. Journal of Environmental Policy and Planning 9(3-4):333-350. http://dx.doi.org/10.1080/15239080701622790

Hobson, K., and S. Niemeyer. 2011. Public responses to climate change: the role of deliberation in building capacity for adaptive action. Global Environmental Change 21(3):957-971. http://dx. doi.org/10.1016/j.gloenvcha.2011.05.001

Jäger, J., L. Bohunovsky, and J. Binder, editors. 2008. Methods and tools for integrated sustainability assessment: project summary. Sustainable Europe Research Institute, Vienna, Austria. [online] URL: http://www.slu.se/pagefiles/58724/matisse.pdf

Kates, R. W., W. R. Travis, and T. J. Wilbanks. 2012. Transformational adaptation when incremental adaptations to climate change are insufficient. Proceedings of the National Academy of Sciences 109(19):7156-7161. http://dx.doi.org/10.1073/ pnas. 1115521109

Kemp, R., and J. Rotmans. 2004. Managing the transition to sustainable mobility. Pages 137-167 in B. Elzen, F. W. Geels, and K. Green, editors. System innovation and the transition to sustainability: theory, evidence and policy. Edward Elgar, Cheltenham, UK. 
Kern, F., and A. Smith. 2008. Restructuring energy systems for sustainability? Energy transition policy in the Netherlands. Energy Policy 36(11):4093-4103. http://dx.doi.org/10.1016/j. enpol.2008.06.018

Lewin, K. 1946. Action research and minority problems. Journal of Social Issues 2(4):34-46. http://dx.doi.org/10.1111/j.1540-4560.1946. $\underline{\mathrm{tb} 02295 . \mathrm{x}}$

Lim, B., and E. Spanger-Siegfried, editors. 2004. Adaptation policy frameworks for climate change: developing strategies, policies and measures. Cambridge University Press, Cambridge, UK. [online] URL: http://www.preventionweb.net/files/7995_APF. pdf

Loorbach, D. 2010. Transition management for sustainable development: a prescriptive, complexity-based governance framework. Governance 23(1):161-183. http://dx.doi.org/10.1111/ j.1468-0491.2009.01471.x

Loorbach, D., and J. Rotmans. 2010. The practice of transition management: examples and lessons from four distinct cases. Futures 42(3):237-246. http://dx.doi.org/10.1016/j.futures.2009.11.009

Markard, J., R. Raven, and B. Truffer. 2012. Sustainability transitions: an emerging field of research and its prospects. Research Policy 41(6):955-967. http://dx.doi.org/10.1016/j. respol.2012.02.013

Markard, J., and B. Truffer. 2008. Technological innovation systems and the multi-level perspective: towards an integrated framework. Research Policy 37(4):596-615. http://dx.doi. org/10.1016/j.respol.2008.01.004

McNiff, J. 2013. Action research: principles and practice. Third edition. Routledge, London, UK.

Meadowcroft, J. 2009. What about the politics? Sustainable development, transition management, and long term energy transitions. Policy Sciences 42(4):323-340. http://dx.doi. org/10.1007/s11077-009-9097-Z

Miller, T. R., A. Wiek, D. Sarewitz, J. Robinson, L. Olsson, D. Kriebel, and D. Loorbach. 2014. The future of sustainability science: a solutions-oriented research agenda. Sustainability Science 9(2):239-246. http://dx.doi.org/10.1007/s11625-013-0224-6

Murray, M. L., E. H. Seymour, and R. Pimenta. 2007. Towards a hydrogen economy in Portugal. International Journal of Hydrogen Energy 32(15):3223-3229. http://dx.doi.org/10.1016/j. ijhydene.2007.02.027

Nevens, F., N. Frantzeskaki, L. Gorissen, and D. Loorbach. 2013. Urban transition labs: co-creating transformative action for sustainable cities. Journal of Cleaner Production 50:111-122. http://dx.doi.org/10.1016/j.jclepro.2012.12.001

O'Brien, K. 2012. Global environmental change II: from adaptation to deliberate transformation. Progress in Human Geography 36(5):667-676. http://dx.doi.org/10.1177/0309132511425767

O'Riordan, T., C. Gomes, and L. Schmidt. 2014. The difficulties of designing future coastlines in the face of climate change. Landscape Research 39:613-630. http://dx.doi.org/10.1080/0142$\underline{6397.2014 .975108}$
Olsson, P., L. H. Gunderson, S. R. Carpenter, P. Ryan, L. Lebel, C. Folke, and C. S. Holling. 2006. Shooting the rapids: navigating transitions to adaptive governance of social-ecological systems. Ecology and Society 11(1):18. [online] URL: http://www. ecologyandsociety.org/vol11/iss1/art18/

Park, S. E., N. A. Marshall, E. Jakku, A. M. Dowd, S. M. Howden, E. Mendham, and A. Fleming. 2012. Informing adaptation responses to climate change through theories of transformation. Global Environmental Change 22(1):115-126. http://dx.doi. org/10.1016/j.gloenvcha.2011.10.003

Pelling, M. 2010. Adaptation to climate change: from resilience to transformation. Routledge, London, UK.

Pelling, M., K. O’Brien, and D. Matyas. 2015. Adaptation and transformation. Climatic Change 133(1):113-127. http://dx.doi. org/10.1007/s10584-014-1303-0

Raven, R., F. Kern, B. Verhees, and A. Smith. 2016. Niche construction and empowerment through socio-political work. A meta-analysis of six low-carbon technology cases. Environmental Innovation and Societal Transitions, in press. http://dx.doi. org/10.1016/j.eist.2015.02.002

Rotmans, J., R. Kemp, and M. van Asselt. 2001. More evolution than revolution: transition management in public policy. Foresight 3(1):15-31. http://dx.doi.org/10.1108/14636680110803003

Sayce, K., C. Shuman, D. Connor, A. Reisewitz, E. Pope, M. Miller-Henson, E. Poncelet, D. Monié, and B. Owens. 2013. Beyond traditional stakeholder engagement: public participation roles in California's statewide marine protected area planning process. Ocean and Coastal Management 74:57-66. http://dx.doi. org/10.1016/j.ocecoaman.2012.06.012

Schmidt, L., A. Delicado, C. Gomes, P. Granjo, S. Guerreiro, A. Horta, J. Mourato, P. Prista, T. Saraiva, M. Truninger, T. O'Riordan, F. D. Santos, and G. Penha-Lopes. 2013. Change in the way we live and plan the coast: stakeholders discussions on future scenarios and adaptation strategies. Journal of Coastal Research 65:1033-1038.

Schmidt, L., C. Gomes, S. Guerreiro, and T. O'Riordan. 2014. Are we all on the same boat? The challenge of adaptation facing Portuguese coastal communities: risk perception, trust-building and genuine participation. Land Use Policy 38:355-365. http://dx. doi.org/10.1016/j.landusepol.2013.11.008

Schmidt-Thomé, P., and J. Klein. 2013. Climate change adaptation in practice: from strategy development to implementation. WileyBlackwell, Sussex, UK.

Smit, B., and J. Wandel. 2006. Adaptation, adaptive capacity and vulnerability. Global Environmental Change 16(3):282-292. http:// dx.doi.org/10.1016/j.gloenvcha.2006.03.008

Smith, A., and F. Kern. 2009. The transitions storyline in Dutch environmental policy. Environmental Politics 18(1):78-98. http:// dx.doi.org/10.1080/09644010802624835

Spaling, H., J. Montes, and J. Sinclair. 2011. Best practices for promoting participation and learning for sustainability: lessons from community-based environmental assessment in Kenya and 
Tanzania. Journal of Environmental Assessment Policy and Management 13(3):343-366. http://dx.doi.org/10.1142/

$\underline{\mathrm{S} 1464333211003924}$

Stirling, A. 2008. "Opening up" and "closing down": power, participation, and pluralism in the social appraisal of technology. Science, Technology, and Human Values 33(2):262-294. http://dx. doi.org/10.1177/0162243907311265

Susskind, L., S. McKearnan, and J. Thomas-Larmer. 1999. The consensus building handbook: a comprehensive guide to reaching agreement. Sage, Thousand Oaks, California, USA.

Tompkins, E. L., R. Few, and K. Brown. 2008. Scenario-based stakeholder engagement: incorporating stakeholders preferences into coastal planning for climate change. Journal of Environmental Management 88(4):1580-1592. http://dx.doi.org/10.1016/j. jenvman.2007.07.025

Voß, J.-P., and B. Bornemann. 2011. The politics of reflexive governance: challenges for designing adaptive management and transition management. Ecology and Society 16(2):9. [online] URL: http://www.ecologyandsociety.org/vol16/iss2/art9/

Voß, J.-P., and R. Kemp. 2006. Sustainability and reflexive governance: introduction. Pages 3-28 in J.-P. Voß, D. Bauknecht, and R. Kemp, editors. Reflexive governance for sustainable development. Edward Elgar, London, UK.

Westley, F., P. Olsson, C. Folke, T. Homer-Dixon, H. Vredenburg, D. Loorbach, J. Thompson, M. Nilsson, E. Lambin, J. Sendzimir, B. Banerjee, V. Galaz, and S. van der Leeuw. 2011. Tipping toward sustainability: emerging pathways of transformation. Ambio 40 (7):762-780. http://dx.doi.org/10.1007/s13280-011-0186-9

Wittmayer, J. M., and N. Schäpke. 2014. Action, research and participation: roles of researchers in sustainability transitions. Sustainability Science 9(4):483-496. http://dx.doi.org/10.1007/ $\underline{\text { s11625-014-0258-4 }}$ 